\title{
Commodification in mass media's educative function in Kenya: How now shall we think?
}

\author{
Benson Kamary
}

6439 N Rockwell St. Chicago, IL 60645 USA.

Accepted 20 July, 2018

\begin{abstract}
Mass media's educative function has had a considerable influence in Kenya since the colonial period. The impact of mass media in shaping the contemporary worldviews-how people see and live in the worldhas led to the transformation in the society. The influence of mass media especially in reinforcing commodification and economic rationalism presuppositions is profound because human beings are fundamentally creatures of habit and mass media contents are characteristically repetitive and unreflecting. Since mass media's images and messages are embedded on philosophical ideas and principles which do not simply develop under spontaneous historical, social, and cultural influences but are products of a fundamental and directing commitment at the core of human thinking, they should be subjected to an authentic critique. From the premise that there is no neutrality in mass media, this paper examines the idea of commodification and its consequences in the society, and calls for a deliberate, thought-out, philosophically consistent approach for reflecting, critiquing and responding to how mass media educates its audience.
\end{abstract}

Keywords: Commodification, mass media, Kenya, economic rationalism, worldview.

\section{INTRODUCTION}

The goal of this paper is to examine the role of the educational function of mass media in shaping audience's worldviews particularly by disseminating economic rationalism and commodification narratives, and to suggest a thoughtful, philosophically consistent approach to holistically understand how mass media form and shape worldviews. The review applies qualitative historical-philosophical literature study approach to explore and analyze the characteristics of commodification, how the media commodifies its contents and the consequences of commodification in the context of mass media's educative function in Kenya.

The term "mass media" is used in this review to refer to television, newspapers and radio as the dominant means of communication. Traditionally, mass media has been understood as to have three main functions: i) to inform, ii) to educate, iii) and to entertain. The educative function of mass media does not necessarily mean a formal instructive program deliberately presenting teaching and learning contents to the audience. Educative function in this study means any educational processes leading to the formation of perceptions and resulting to behavior change.

\section{The popularity of mass media in Kenya}

When a middle class Kenyan living in a major city like Nairobi wakes up in the morning, he or she usually listens to the news on radio or watches the television and peruses the newspapers before starting the day's work. To a considerable extent, most of his or her conversations and decisions are based on or are influenced by the information from the media. Indeed, the media sets the agenda for public opinions and shapes peoples' perspectives because the Kenyan media is largely considered as a genuine institution for information, education and entertainment.

According to a research study by Gallup International in March 2009, the media institution was the most trusted 
with over 80 percent of Kenyans giving it a favorite approval. Tom Wolf, a lead researcher at Gallup International noted that Kenyans are putting their last hope in the media while their trust for other institutions is at an all-time low. The Standard, one of the mainstream newspapers reported that an overwhelming 89 per cent of the 2,007 respondents approved of the press, commonly known as the Fourth Estate (Opiyo, 2009). A poll conducted by Infotrak in 2016 showed that 87 per cent of Kenyans had confidence in the media and were content with the informative, educative and watchdog role of the journalists (Ngetich, 2016). Another research findings by Kenya Tech News concluded that traditional media in Kenya was the most trusted source of news, with television as the most esteemed, followed by radio and newspapers respectively (Daniels, 2017).

Evidently, there exists a commanding confidence in the media. However, mass media is known to subtly make people complacent and reluctant to critique the worldviews disseminated via the media's images and messages. According to McCombs (2014), the agendasetting role of media influence in shaping the audiences' minds and perceptions is both subliminal and enormous. Mass media instructs and shapes the thinking and opinions by advocating a particular ideological view point. Through the educative function, mass media not only imparts information and knowledge; but also transmits values through its content and programming. As Dill (2009) observes, radio and television generate changes in cognition and comprehension, affecting concepts by re-defining what is normal, emotional arousal, sex and behavior identification. More so, they influence allocation of time, consumer purchase, and voting behavior. Thus, mass media is collectively a powerful tool that can potentially shape the ultimate framework of ideas and beliefs by which an individual understands and interacts with the world-a person's worldview (Katz et al., 2017).

\section{Commodification: What is it?}

Commodification is a process through which social relations are reduced to an exchange relation or what Karl Marx refers to as callous cash payment (Marx, 1867a). It is also defined as the transformation of a noncommodity into a commodity or assigning a monetary value to something that traditionally would not be considered in monetary terms, for example an idea, identity or gender (Tomsic, 2015). Frankfurt School's Neo-Marxist critical theory directly relates to culture industry upon which commodification thrives. It also relates to Georg Lukács theory of reification presented in History and Class Consciousness in 1923. Lukács offers a concept of reification (Verdinglichung) through a Marxian definition, that is, reification is the phenomenon and the resulting occurrences of a "definite social human relations" emerging in the form of a "relation between things" (Honneth, 2008: 23).

The term commodification originates from Marx's notion of commodity fetishism; however, its connotations can be traced back to Adam Smith and his deep ambivalence about the moral implications of markets and competition. Marx referred to commodity fetishism as the 'mystery of the commodity form'; the simplest and most universal example of the way in which the economic forms of capital conceal underlying social relations. The concept deliberates the social relations conducted in the form of relations between commodities or things (Tomsic, 2015). Plumwood (2002) asserts that the economic rationality of capitalism, whose essential characteristics are the identification of rationality with egoism and competition and the interconnected concern to exploit property formation and economic development, supports strategies that decrease ethical acknowledgment of the other-than-human world. However, as Akrivou and Sison (2016) notes, economic activities are to be understood as human actions by actual humans through collaboration based on certain anthropological and cultural foundations which advance virtue ethics.

Commodification, however, is a thought that expresses outcomes in terms of their monetary value often without virtue ethics. For instance, educational success is commodified if re-defined as a means to attain a good job and a "huge" pay. From this viewpoint, a government would see education as a production process and graduates as potential economic cogs to gear the production engine. Mass media has in effect regarded culture and cultural aspects as a theatre of operation keeping the public in an acquisition treadmill powered by postmodern consumerism-a key feature of economic rationalism -through its captivations of ever-consuming fans (Taylor and Harris, 2008).

In the context of globalization, mass media tend to reinforce existing patterns of local cultural perspectives and act as entry point for 'foreign' worldviews (Kamary, 2013). To appreciate the impact of commodificationprocess by which things, services, ideas, and people relations are transformed into objects for sale in a capitalist economic system - one must begin by critiquing the worldviews imbedded in the messages and images in mass media. Hearn (2015) notes that the consequence of commodification is that human practices which are normally considered to be outside of the 'marketplace', such as courtship, art, religion, education, medicine, are commodified and integrated into the capitalist 'marketplace'.

\section{CHARACTERISTICS OF COMMODIFICATION IN MASS MEDIA}

\section{Capitalism}

According to Karl Marx, commodity is the heartbeat of 
capitalism since the wealth of those in societies where the capitalist mode of production is dominant, presents itself as an immense accumulation of commodities; its unit being a single commodity (Marx, 1867a). For Marx the commodity is the 'economic cell-form' (Marx, 1867b: 19). In capitalistic system, commodities are bought and sold in markets where a willing seller and a willing buyer converge.

Kenyan capitalism has its roots from the Western worldview. This worldview entered during colonization in early 1900 s and has become the prevailing mega narrative. Modern capitalism in Kenya has seemingly been influenced by neo-Hellenism and the philosophy of an individual autonomy, epistemological dualism, material prosperity, scientism, globalization and economic rationalism (Thornton, 2000). Mass media through popular culture embedded on Western capitalistic worldview has informed people's way of thinking and thereby replacing the traditional African communal view of life and moral responsibility to the community.

Perhaps the greatest impact of the Western capitalism on Kenyan culture is the twin characteristics of economic rationalism and commodification because "...they [media] represent a subtle but pervasive vehicle for the enhancement of capitalist dynamics and commodity values" (Taylor and Harris, 2008: 107). On the other hand, those who rooted for a capitalistic approach, argue that free enterprise systems will promote diversity and disparity between them and will not allow them to serve private interests (Ziegler and Asante, 1992: 127-128).

Kenyan commercial media is certainly capitalistic, and this has encouraged media cross-ownership of the media channels. For example, the Nation Media Group (NMG) runs 69 media brands including newspapers, radio and television stations across the East African countries. Royal Media Services also operate 17 radio and television stations across the country according to the Communication Commission of Kenya (2018). Although there is nothing wrong in building media business empire, critics have often raised questions in regard to the concentration of media outlets particularly those owned by politically influential individuals as well as those with multibillion business interests (Maweu, 2014).

Capitalist democracy hardly restrains itself from absolute exploitation of the media, and with a progressive and pervasive medium, emerges new possibilities for exploitation. The thriving of cable and satellite broadcasting in Kenya have blurred the perception of what is appropriate for public consumption since they have also introduced their own regulations including when to broadcast adult contents. In response, the Kenya Film Classification Board (KFCB) recently proposed several changes vis-à-vis the publishing and broadcasting videos for public consumption especially those depicting contents that would allegedly corrupt the culture and the moral value of the Kenyan people (Mbenywe, 2018).

\section{Economic rationalism and culture industry}

Economic rationalism is the belief that if something is good for the economy or for profit it is incontestably good to pursue. The culture industry is a thesis proposed by Frankfurt School's which asserts that cultural industries exist to enforce (or reinforce) the capitalist culture (Adorno and Horkheimer, 1993). It is also referred to as a mass culture or pop culture which capitalism uses to control the individual consciousness thereby "industrializing" and commodifying relationships through aura and manipulation of desires (Taylor and Harris, 2008). Contrary to traditional understanding, "industry" in this context does not necessarily mean the industrial production process, although much of culture commodification occurs by this means. According to Grant (N.D), an industry is the standardization and pseudo-singularity of cultural items, and the regulation of how they are promoted and distributed. Much of the effects of capitalistic life, no matter how pleasant or unpleasant, are results of inherencies in the capitalist system (Tomsic, 2015).

Economic pressure in the press and broadcasting has forced the media to be selective in using particular sources, words and images, themes and orientations to reach the broadest range of potential audiences within the mass culture (Taylor and Harris, 2008). The quest for profitability as a vital means of media's survival has also intensified the limitations of the media as the "fourth estate" or as "watchdog" in the society. Musa (1996) notes that there is no neutrality in how the media selects news content:

...the media are not haphazard in the way they select their news items even from among statements by the elite. Each paper [radio or TV] for example has its own areas of interest depending on its organization and technical framework and its target audience. Such differences are what produce the different social personalities of newspapers [radio or TV]. The question that may [also] arise is how newspapers come to cover the same stories in their pages. (p. 86, 87)

Because the media has its lifeline for survival and expansion in advertising revenue, media firms have taken radical capitalistic profit-making approaches. The problem with these strategies, as some critics have pointed out, is that the rich and businessmen elite can easily control not only the media institutions, but also their contents (Hennessy, 2018) and thus influence how people make choices.

\section{Post-modern consumerism}

The postmodern era and consequently the postmodern 
worldview produces an individualistic, consumer driven society. As Bendiksen (2017) suggests, postmodermity is a culture of consumption since everything is perceived as a consumer item including knowledge, meaning, truth and spirituality. Consumed by mass media's network and influence, post-modernity aims at marketing products to consumers, emphasizing the quest for the shelf (products) rather than of self (relational human being) (Cray, 1998). Beed and Beed (2017) argue that the pervasiveness of postmodernism today is completely saturated and dominated by the forces of modernity in which the very definition of what modernity means is left hanging in the air. The economics of postmodernist is the economy of desire, that is, when desire is taken to be the fundamental human power (Beed and Beed, 2017).

Postmodern narrative is complex, and its critics hold varying perspectives especially when dealing with its form of capitalism that essentially cannot be represented comprehensively. The most common or agreed upon definition of postmodernism is the absence of a center or a single narrative that ties together its core beliefs (Bendiksen, 2017).

Contemporary trends show that Kenyans exposed to mass media, especially the urban population, are likely to seek approval for their fashion trends as well as eating habits and response to topical issues from the media (Anami, 2007). Television's impact in propagating economic rationalism manifests itself in the culture and captures the desires and realization of the public from all aspects and advances the objective of individual possessions. According to Cray (1998), an ideology like post-modernistic consumerism in the end distorts genuine norms and values. They are packed with new contents until they become functional tools in motivating people to pursue the commodified end. Western culture adopts this consumerist strategy and the Kenyan media, having been informed by Western worldview, appears to be perfecting the same ideology through advertising and deliberate profit-making programming.

\section{HOW THE MEDIA COMMODIFIES IMAGES AND MESSAGES}

\section{Advertising and product placement}

Mainstream media heavily depends on advertising for operation. Commercially run media stations are primarily financed through advertisements placed by the government, private companies, NGOs, individuals or sometimes through subsidies by revenues from profitable enterprises owned jointly with the media companies.

According to PricewaterhouseCoopers Inc $(\mathrm{PwC})$ report on entertainment and media (E\&M) industry in Kenya, Ghana, Tanzania, South Africa and Nigeria, the Kenyan entertainment and media market was worth US\$2.1 billion in 2016, up 13.6 per cent on 2015. The advertising revenue is expected to grow at an average of 8.5 per cent over the subsequent five years, totaling US\$ 3.2 billion by 2021 (Ndegwa, 2017).

Consequently, this state of advertising dependency produces an editorial position that is pro-business or supportive to a given political agenda with democratic implications (Levy and Nielsen, 2010). More so, editors are likely to choose, consciously or unconsciously, advertising and contents that attract their targeted advertisers in the audience segment. For instance, analysis by Maweu (2014) revealed a clash between journalistic and capitalist values in how advertisers meddle in journalists' decisions at the Nation Media Group, one of the largest media companies in Kenya. The clash is rooted in the critical political economy of the media tradition highly imbedded on economic rationalistic idea of maximum profits at the expense of virtue ethics.

Advertising seeks to maximize profits by employing all manner of tactics to capture the attention of the audience. Rosenstiel and Kovach (2014) observed that mass-media culture would even erode cultural values so that low, middle and intellectual groups become constituent of consumer ratings and nothing more. In essence, the very relationship between the media and the audience is commodified.

The creation of hedonistic but fake values and dehumanizing images are sometimes established in order to increase profits. In such a strategy, advertising campaigns which appeal to emotions have been thought to be as effective as they are successful because emotionally based advertising is capable of influencing brand choice in any category no matter how deleterious the consequences are. As Damasio (1995) claims in his book, Descartes' Error, the reason why advertisers use emotional appeal may not be as pure as most people think, neither is it a luxury since they are indispensable to rational thinking. Jhally (2017) suggests that advertising does not mirror how people are acting, but how they are dreaming. In other words, mass media advertising taps into the audience emotions then re-conceptualizing them and reconnecting it with the world of commodities.

Product placement at prime time when most of the target audience can be reached and within popular programs like foreign soap operas and local dramas is one of the common strategies to reach out to a wider audience. Advertising companies and media appear to have entered into a new era of product placement, corporate sponsorship, and advertising campaigns in which the "promotion of a 'lifestyle' or 'brand' is given a greater priority than that of any particular product's concrete qualities" (Taylor and Harris, 2008: 70). According to the Kenya Film Commission's audience consumption trend survey, TV viewership in Kenya remains high with $59 \%$ of Kenyans being exposed to television viewership daily (Kenya Film Commission, 2017). 


\section{Information placement and idea placement}

Free flow of information and knowledge accessible to every citizen has traditionally been seen as an essential precondition for cultural, social and economic development as well as for a healthy democratic process (World Summit, Geneva, 2003). However, there is a shift of thought where information is no longer a public good, but a commodity processed and packaged like soap or automobile and sold to the affording few. The concept of information economy has emerged out of the growth of entrepreneurship in the media sector and along with advertising comes idea placement-a deliberate move to have a particular message integrated in the aired media content. These 'fixed' messages take diverse forms; political or business and it is made to sway the audience to think or act in a certain way. Adorno and Horkheimer (1993) asserts that the media mass culture industry seeks to construct and put complex ideas inside the audience's awareness - the psychoanalytic perception of a multilayered persona has been taken up by the mass media culture industry in order to trap the audience so as to direct them subliminally.

As Kenyans watch popular television dramas, sitcoms and comedies, they are likely unaware of the principal elements of the capitalistic ideology placed in these programs, which Harris and Taylor (2008) describe as "colonizing commodifying logic whose grip on the individual and collective has grown ever firmer in the intervening decades" (p. 84). In Kenya, there exists a form of a new mass culture trickling from the urban society towards the rural population-a kind of enslaving commodifying routine whose clench on consumers is dictating expenditure and the operations of their home economics. This description mirrors the wider state of affairs of production, which are those of standardization and optimization, in favor of strategically designed ideas placed to increase profit. Mass media culture, therefore, becomes a celebration of commodification ideas. As Taylor and Harris (2008) observe, rather than media producing a qualitative transformation that offers new forms of social empowerment, it represents a subtle but pervasive vehicle for the enhancement of capitalist dynamics and commodity values. Although information and idea placement is a common strategy in mass media advertising, it could be easily be a conduit for colonizing commodification presuppositions for both commercial and public media (Kamary, 2013).

\section{Commodification of audience segments}

Mass media tends to categorize target audience segments by age, sex, region and economic classes to make maximum coverage and consequently boost profitability by attracting potential advertisers. On the other hand, this approach leads media companies to deliberately minimize risks of missing out on profits by shunning unfamiliar areas that may lead to unfavorable reception by the audience and consequently advertisers. For example, Maweu (2014) notes that there has been existence of a clash between journalistic and capitalist values in how advertisers meddle in journalists' decisions in Kenya. In the context of highly commercialized media environment in Kenya today, market forces pose the greatest threat to media freedom and responsibility. The media focuses on profitability by providing space and attention only to the target audience and location of coverage identified for audience retention. These are areas and issues that are deep-rooted and well-known to audiences' sensibilities. This very characteristic of divisionism in the media based on individualistic 'atoms' is unfamiliar to the core of Kenya's African concept of socialized community. From an African perspective, mass media serves the entire community as a unit (Kamary, 2013).

\section{Commodification of entertainment and celebrity cult}

There has been an increasing proliferation of entertainment media or what can be termed as palliative media. Radio and television music programs in the Kenyan media context have continually redefined or reinterpreted the young people's perspective of what it means to be a successful youth. The media has tapped into pop-culture and the obsession of 'celebs' painted as autonomous, self-confident and financially fulfilled; qualities that are absent from most consumers (Taylor and Harris, 2008). Celebrities as spectacular representations of a living human being promote the illusion of equal success and fulfillment which in reality is a shallow life that has to compensate for the fragmented productive specializations.

Kenyan celebrities, mostly young musicians, comedians and those from various units of media fraternity, have been elevated by such avenues as Pulse Magazine, MTV, Channel $O$ and East Africa Tv as well as Christian music programs like Stomp of NTV, to a near cult status. Attention given to these celebrities is a deliberate crowd-pulling 'spanner boys (and girls)' only decorated as magnificent representation to promote the illusion of equal access to the totality of consumption. At times, celebrities are created out of an advertising character and thereafter attract a big following with an image of freedom that media portrays them as possessing. Studies have shown that endorser-product congruity positively affects consumers' perceptions of spokesperson credibility, freedom, attitudes, recognition, purchase intention, and willingness to pay higher prices. The characteristics of such a celebrity is framed to often match up with the dominantly appealing attributes of the brand in order to attract more customers (Djafarova and Rushworth, 2017). 
Health (2001) asserts that "all young people seek freedom and independence [and that attitude] goes deeper than being a simple personality to aspire to" ( $p$. 84). However, there is a fundamental schism between a celebrity and the individual whereby the celebrity is turned to be the enemy of the individual only sustained by the power it has accumulated. Taylor and Harris (2008) note:

Moreover, entry into the charmed circle of celebrity involves the systematic suppression of the spontaneous individuality 'passing into the spectacle as a model for identification' the agent renounces all autonomous qualities in order to identify himself with the general law of obedience of the course of things' (p. 127).

\section{Commodification of the human body}

Commodification of the human body in mass media advertising and 'harmless entertainment' replicate a celebration of the logic of the capitalist production. Kracauer (1995) in The Mass Ornament, suggests that the Tiller Girls underwent a literal embodiment of the disembedding or de-territorialization effects of capital, that is, the women who make up the spectacle are deindividualized. The fate of the individual body serves as a microcosm of the fate of the body politic as capitalism disarticulates the latter's natural organs and recombines them in accordance with the prescriptions of production even when supposedly in the service of art or entertainment" (Taylor and Harris, 2008: 49).

The human body, Kracauer (1995) refers to as the mass ornament, is disintegrated and divorced from its constituent parts to resemble the pure lines of 'Euclidean geometry' or the simple forms of physics. The mass ornament is thus viewed as an inorganic, abstract order and as such the structure of the mass ornament reflecting the entire capitalist situation. The most effective brand associations, such as associating a product with a celebrity or part of their bodies, are those that trigger a benefit or an established marker of some kind. Brand associations cannot only become powerful branding strategies, but more significantly, can convey powerful and hidden meanings that insidiously influence the way we select brands (Charlton, 2014). A celebrity, including his or her commodified body parts-thighs, bust, lips or bottoms mirrors our similarly ambivalent yet routinized relationship with the branded commodity alongside other promotional elements in packaging; color, shapes, logos, and music, making the biggest single group of unique brand association of all (Khandizaji, 2017). The emphasized relationship between the product and the celebrity leads to the creation of new life style and fashion particularly for the younger audience whose selfesteem is still at the formative stage where values and attitudes are shaped. The product and celebrity appeal become influential as they are perceived to be more authentic and accessible (Djafarova and Rushworth, 2017).

The notion of celebrity has become an industry, that is, economic rationalism is using media to manufacture celebrities as attention-getting bodies whose fame turns them into economic units. Consequently, the celebrity status is commodified within them. Media personalities have been commodified through the expanding amount of attention that can be given to contingent detail in triviabased personality-dominated chat shows and lifestyle programs. Moreover, the role of television personalities with strong charismatic authority and strong personality traits becomes a unique selling point for commodified relationship between the media and the larger audience. This combines with the structure of programs to reinforce television's role as an ideological support for commodities. For example, Taylor and Harris (2008) note that a program's celebrity presenter becomes an individual brand or the presenter's work within a show is itself branded and franchised. In some cases, the strength of the program is deliberately used to sell other brands during the commercial breaks. Kenya's Churchill Show and Jeff Koinange Live (JKL) are typical examples of a presenter's branded television programs.

\section{Commodification and distraction}

Advertising elements including celebrities, music and color, particularly on the television, arising from economic rationalism, fuel the culture of distraction today. Rojek (2001) argues that the "society requires distraction so as to deflect consciousness from both the fact of structured inequality and the meaninglessness of existence..." ( $p$. 90). Rojek's observation reflects a postmodern worldview evident in Kenya. The commercial mass media has emerged to monopolize or distract the attention of the masses so effectually that the alternative media sources and voices are drowned out. For example, Charlton (2014) notes in book, Addicted to Distraction: Psychological Consequences of the Mass Media, that the media tend to focus on or ignore certain topics without reference to their importance or merit. While some contents are portrayed as intensely urgent or critical news others become blatant distraction including; famine relief in Africa; sacking of a celebrity for making a 'gaffe'; honoring a sports hero; celebrating of a Royal Wedding or the World Cup or a pop star funeral; imprisoning a sexual offender; the wonderfulness of a particular new car or computer; taxing 'carbon'; or subsidizing an opera house. In the midst of such distractions, commodification narrative remains pervasive.

Gamson (1994) and Khandizaji (2017) argue that a strong element of the culture industry is the way in which the surreal power of commodities relates less to overt 
ideological manipulation and much more to the way in which we practice their magic upon ourselves. Gamson wondered why such widespread interest and consumption existed in the face of what ought to be extremely damaging, even shameful, revelation of technique and how the celebrity system survives, even thrive, under these conditions.

Mass media continue to utilize numerous outright commercially based distractions. Television's superficiality has its primary status as an overwhelmingly domestically situated medium, in concurrence with its close links with advertising business. In this context, the media plays a major political function connecting the expansion of capitalism and increasingly privatized and domesticated forms of consumption.

\section{CONSEQUENCES OF COMMODIFICATION}

The media engages in reproducing views and opinions using words and images embedded in the worldview held by the producers, scriptwriters, journalists and business interests. These reproduced views and opinions are fashioned to be crowd pullers and they take the role of an educator in imparting philosophical perspectives by taking advantage of reactionary populism fueled by persistent and strategic modes of publicizing. Kasoma (1996) laments the way in which economic rationalism is getting rampant in African media context driven by selfish motives of profit maximization and political expediency.

Commercial television broadcasting thrives in homogeneity and since commercial television is largely supported by advertising revenue, it requires steady popularity. In this context, the most popular shows are developed and screened with the purpose of appealing mainly to a passive and uncritical audience amid the pervasiveness of the commodified ideology. Unfortunately, many young journalists working in the media industry are products of commodified education which finds itself in preemptive capitulation or giving in to the economic rationalist worldview without engaging it, critiquing it and responding to it reflectively.

\section{Commodified education}

To say that education has been "commodified" is to claim that education is understood as a value in the form of commodities that are bought and sold in market. To comprehend commodification of education is to think about the business agenda for and in education, and the production of labor power as human capital for businesses (Alexiadou, 2001). It is also referred to as capitalization; turning schools and universities into currency value or commodity producing enterprises (Rikowski, 2003).

Viewing education as a commodity has led many
Kenyans to think of education as something to be purchased for satisfaction. This approach reflects the analysis of Jean Piaget, in Cherry (2018), a developmental psychologist and a proponent of the view that students are merely cognitive beings, empty vessels to be controlled by specific inputs and expected outcomes. But seeing education as a "thing" is reductionistic and leads to its commodification rather than comprehending the concept of education as a complex network of relationships, intent, motivations, cognitions and desirable outcomes. Commodified education's outcome is perceived as 'packaged' good for sale.

Commodified education also leads to the economy of student worth, that is, thinking of student's success through the lens of performative culture. This view tends to change the social relations between providers and clients as well as the school and the parents. From this standpoint, education increasingly becomes subject to the normative assumptions and prescriptions of economism and not a relational venture involving real people (Kamary, 2013). Since commodified education views students as clientele, the qualification they earn is a commodity readily exchangeable for a job rather than equipping students for a meaningful life.

\section{Commodified relationships}

Pre-marriage relationships in Kenya have been impacted by economic rationalism thinking. Although marriage can be viewed from different perspectives-religious, cultural or civil-a recent Legislative Bill to review marriage and the family generated uproar among Kenyans particularly the recommendations to outlaw dowry giving. Majority of Kenyans rejected the proposal terming it a threat to the sanctity of marriage while others rebuked the drafters of the Bill for borrowing profoundly from the contemporary Western concepts of marriage (Global Legal Monitor, 2014).

Grunlan and Mayers (1988) observed that every community has an established concept and activities related to marriage. In some cultures, specific social and economic mechanisms that encourage the maintenance of the family ties include the bride prize or dowry. From an African traditional point of view, bride prize or dowry has been a symbol of gratitude to parents of the bride. Giving of dowry, a longtime custom in most African tribes, has however changed form to monetary essence-from cattle and farm produce-owing to the fact that not many people keep livestock in this age and time. Although this change was inevitable in a globalized world, the dowry custom was traditionally intended to represent gratefulness and reinforce the relationship between the bride and groom's families. Viewing courtship and marriage mainly from a monetary point of view is a characteristic of commodification and commodification distorts the initial purpose of dowry (Kamary, 2013). For 
example, a conflict between Francesca, a bride to be, and her mother is a prime example of a commodified relationship. Francesca's mother suggests that because her daughter is educated and 'well mannered' she is keen to collect a payment of 500,000 Kenyan shillings $(\$ 8,000)$ in dowry, a suggestion that Francesca opposes arguing that she is not a commodity to be purchased (Santoro, 1998).

Mass media has been the most influential tool in shaping contemporary worldview in relationships, sexuality, marriage and family. Successful marriage relationships have been portrayed in the media as that of a wealthy couple with high paying jobs, latest cars and big houses. Borrowing heavily from mass media's definition of beauty, romance, sexuality, courting and marriage has misled many young people to shun African traditional values and religious values that have informed the Kenyan culture for decades. The contemporary young people are in darkness as far as manipulation by the media's ideological placements and profit-making agenda. The media uses the so-called young celebrities who use sensual messages and images from a distorted perspective and leaving many other in some warped imaginations about what courtship, marriage and family really means (Akrivou and Sison, 2016).

\section{Commodified self}

Individualism is one of the greatest threats to an African view of communication because in African context, communication is a service to the community. Contemporary Sub-Saharan African media have their theoretical ethical foundations, goals and objectives in the blueprints of the Western media. Kasoma (1995) warns that African journalists refuse to listen to any suggestions that journalism can have African ethical roots and still maintain its global validity and appeal. Anyone suggesting that Africa can teach the world some journalistic manners has been declared "anathema" (Kasoma, 1996: 94).

Commodified self emanates from radical individualism. In journalism, this ideology of individualized and imitational approach to reportage lead journalists and their media companies clasp jealously to the content of their reporting. Christians (2004) suggests that the moral duty of the media in an African context should be directed first and foremost to the society followed by professional colleagues. By throwing away a society-based approach of journalism, African journalists lack discernment of the cultural perspectives involved in their journalism environment. At the heart of African worldview is the collective view of life. Individualism in the context of commodification is often seen as eroding relationships by reducing and at times eradicating opportunities for real conversations. Taylor and Harris (2008) assert that television colonizes the domestic spheres by becoming the electronic hearth of flickering images around which family life increasingly resolves "while providing a pseudo society for those deprived of the real thing" (p. 82).

While many people perceive media as a social empowerment, and it could be, there is little, if any, thought that media empowerment should include the ability of the audience to challenge or even question the fundamental essence of the media's influence to their social circumstances. Examination of lifestyles and fashions among Kenyan youths reveal the educational impact of the mass media in forming perceptions of a 'good life' (Kamary, 2013).

\section{The loss of African ethics in Kenyan media}

From an African ethics or Afriethics perspective, life in a community is paramount and human persons realize themselves as individuals through the community. In this context, there is no individuality without the community. Differing views in the community life are reconciled and individuals are given an opportunity to participate in the process of moral discernment. Bujo (1992) clarifies that the emphasis on community in African ethics should not be construed as replacing individual responsibility in moral decision-making and actions.

From an African understanding, an individual exists because the community exists. Relationship of the human being to the community goes further than community life. It involves interdependence: people, animals and environment exchanging their strength and are in an osmotic relationship. Thus, the community and individuality are not opposites. Every individual is supposed to contribute to the well-being and the maintenance of these relationships. Christians (2004) suggests that Africans, including the highly urbanized elite, still maintain a good deal of the beliefs and values fostered by the pre-colonial era. He observed that the Afriethic values organized based on kinship and still tied to rural areas, have served to humanize African society, including the mass media systems.

Nevertheless, many contemporary African communities may not have the cultural and social structures of afriethics due to changes brought about especially through western education and civilization responsible for the introduction of individualism and capitalism. However, there have been attempts by African scholars and policy makers to protect African values by proposing regulation in mass media content.

In Ghana, for instance, the impact of globalization has been impactful to economics, politics, culture, and the media. As Nuviadenu (2017) notes, western worldview perspectives in local media context have either been resisted or compromises made to allow only some selected contents in the quest to maintain national identity through media policies for local stations.

In Kenya, the Kenya Film Classification Board (KFCB) 
recently banned a film titled 'Rafiki' because it contained homosexual scenes and therefore offends the sensibilities of the Kenyan people. The ban was implemented despite the film receiving several invitations from prestigious film festivals in United States of America (Rajula, 2018).

\section{HOW NOW SHALL WE THINK?}

\section{Acknowledging the impact of commodification narrative}

As commodification narrative in the media becomes pervasive, there is more evidence of ordinary people's understanding education, marriage, politics and governance from an economic point of view. The influence of mass media especially in underpinning commodification is profound because human beings are fundamentally creatures of habit and our relationship with the media is habitual. Carr (2011) expresses McLuhan's notion of technology by asserting that every technology is an expression of human will and every medium is an extension of humanity.

The media professionals: writers; musicians; producers and journalists make and remake songs, stories, dramas and news items that selectively embody and frame the myths, issues, conflicts and ideals of the existing culture. However, most consumers of the media naively accept this selective interpretation of reality without much questioning since it appears amusing and entertaining. The mass media tend to reinforce and reflect the dominant social, political and cultural assumptions mostly informed by economic rationalism. Since there is no ideological neutrality in media, the media contents should be subjected to a reflection and a critique from an authentic perspective.

A realization of how much perception of the world is filtered through the media screen and airwaves leads to aspirations for alternative ways of understanding the media's educative framework. Once the illusion that the mass media offers us an objective, transparent view of reality is exposed for the lie that it is, numerous questions arise irrespective of what the particular media arrangements are within the culture. These may be: questions about the ideological or political bias of news and documentaries, questions about the media portrayal of social, cultural and tribal alliances, questions about the values and attitudes presented through popular dramas, films and comedy shows, questions about the crossownership, the control and organization of broadcasting or the press, and questions about the possibilities for minority's points of view to be expressed.

\section{Rethinking mass media's educative function}

A critical engagement in mass media's educational function, complex as it may be, requires a shift from blind conviction to systematic analysis of all that technologically advanced mass media has to offer including its promise of a better future in an appeal to novelty and material acquisition. However, the critical analysis, though useful and necessary, is inadequate if it only develops skeptical media consumers and the government operatives. Instead, a critical analysis should also generate an informed critical appreciation because developing a critical awareness of the mass media milieu and mass media content deepens a meaningful perception of media culture. Reflecting on the nature, design and the impact of mass media's educative processes, encourages people to be better communicators. Such a reflection would refine peoples' understanding of communication process and equip them to deliberately engage and enrich mass media to reflect an authentic way of thinking and living (Kamary, 2013).

From an African point of view, the community is the prime educator within all educational enterprises. Education is understood in terms of a socially transformative interface where the communal philosophy presupposes the way people see and interact with the reality. Africans see human events as inherent interplay capable of initiating communicative transformation in which, "a move or word from one person modifies or changes his position in light of the second person's move, and so it goes" (Ogbonnaya, 2001: 45). Thus, learning takes place in accordance to a person's involvement in events because events are what give education narrative impetus. Educative function of mass media is therefore effective if seen as social action; a cultural phenomenon of informing the minds and forming the hearts of the audience. This perspective has its basis on the fact that most Africans connect reality with the supernatural. Mbiti (1991) observes that to Africans, this is a religious universe and in its broadest sense of the word, nature is not an "empty impersonal object or phenomenon: it is filled with religious significance" ( $p$. 25).

To rethink mass media's educative function from a holistic view means recognizing the media's own ideological biases in its main functions of informing, entertaining and educating the masses. Both commercial media and public media in Kenya are understood as 'the fourth pillar of democracy' along with judiciary, executive and legislature, and have played critical role in the development of human rights and political freedoms through their educative functions (Kamary, 2013). From historical development of free speech in Kenya, the media have always been regarded as champions of the masses government's repression (Schmidt, 2015). However, with the pervasive idea of commodification embedded on media's images and messages, a reflection of the educative function of mass media is necessary in light of traditional African ethics.

In fact, a reflection on contemporary media's influence calls for a deliberate cultural engagement with purposeful 
attentiveness to the existing presuppositions, persistence and willingness to transform how people think about mass media and its transformative ability to impact core values (Kamary, 2013). In the contemporary Kenyan context, the media professionals_including media educators-should pay particular attention to the forces of economic rationalism and begin equipping the populace and would-be media professionals to be aware of its powerful impact in the society.

The application of mass media's educational function from an authentic worldview perspective is essential since the media is the dominant lens through which people see the world, and for this reason, the media shapes worldviews (Jethani, 2012). Daily interactions with mass media's images and messages and their characteristics of repetition and abundance have lasting effects on users' lives. The educational role of media can generate changes in cognition and comprehension and re-defining what is normal emotional arousal, sex and behavior identification and changes in allocation of time, consumer purchase and voting behavior (Dill, 2009; Hennessy, 2018). Without a discerning wisdom that offers guiding values, the media will continue inducing lives in a cleverly entertaining way-what Postman (1985) describes as amusing ourselves to death.

\section{CONCLUSION}

The theme of this paper was built on the premise that there is no neutrality in mass media content. The media act as a channel through which philosophical ideas are reflected, disseminated and taught often at a presuppositional level. Since these philosophical ideas and principles are powerful and develop under specific historical, social, and cultural influences, they should be subjected to a reflective analysis.

With a robust sense of trust in media as a dependable source for information, education and entertainment, radio and television in Kenya enjoy strong approval from the audience. However, beneath the façade lies fundamental need for a critical awareness of the ways the media shapes how people see, live and respond to issues - their worldviews. This critical awareness must begin not with the content of the mass media, but with the ubiquitous nature of mass media and its power to transform presuppositions. For a long time, the critique of the fundamental educational function of media, has been unjustly neglected largely because of the commonly accepted perception that mass media content is neutralas speaking for the good of the common man-rather than reflecting the worldview commitment of media barons and their supporters or reflecting the cravings of a gullible society, or the expansionist profit-driven ambitions of producers' intent on increasing their market share.

Indeed, the values, ideologies and concepts that the media delivers in its educational agenda are a product of beliefs and values of people behind the microphones, those in the production rooms and or the media owners and their sponsors. As Richard Salent, the former president of CBS News once asserted, "Our job is to give people not what they want, but what we decide they ought to have" (Burien, n.d., para. 9).

Since there is no neutrality and all forms of education constitute a liturgy - a fundamentally pedagogical conduit for informing and forming worldviews-there is a critical need to critique mass media's educator function. Such a critique must focus on the foundational presuppositions of the media's images and messages particularly those that underpin radical commodification.

To critique the fundamental context of mass media's didactic role calls for a clear understanding of the true character of mass media and the prevailing life views amid the excessively optimistic and entertaining media environment in Kenya. Discerning audience and critics should raise the exigency for authentic reflections and critiques to redeem the educative function of media from the undesirable consequences of commodification. A meaningful role of mass media regarding educating the masses must edify human relationships as intrinsically special while avoiding any attempts to commodify human relations, personalities or bodies.

\section{REFERENCES}

Adorno, T., and Horkheimer, M. (1993). The culture industry: Enlightenment as mass deception. Retrieved from http:// hamp.hampshire.edu/ cmnF93/culture ind.txt.

Akrivou, K., and Sison, A. J. G. (2016). The challenge of capitalism for virtue ethics and the common good. Cheltenham, UK: Edward Elgar.

Alexiadou, N. (2001). Management identities in transition: A case study from further education. The Sociological Review, 49(3): 412-435.

Anami, K. (2007). Kenya: Catwalk Kenya puts local fashion industry in the spotlight. allAfrica.com. Retrieved from http://allafrica.com/stories/200711201150.html.

Beed, C., and Beed, C. (2017). A postmodernist theologian's critique of capitalism. Journal of Religion and Business Ethics, 3(7).

Bendiksen, K. (Spring, 2017). Postmodernist fragmentation and nonlinearity: An experience of time within the capitalist framework. (Unpublished thesis). University of Oslo, Norway.

Bujo, B. (1992). African Theology in its Social Context. Maryknoll, NY: Orbis Books.

Carr, N. (2011). The shallows: What the Internet is doing to our brains. New York, NY: W.W. Norton.

Charlton, B. G. (2014). Addicted to distraction: Psychological consequences of the mass media. Buckingham, UK: University of Buckingham Press

Cherry, K. (2018). Jean Piaget Biography (1806-1980). Retrieved from https://www.verywellmind.com/jean-piaget-biography-1896-19802795549.

Christians, C. G. (2004). Ubuntu and communitarianism in media ethics. Equid Novi: South African Journal for Journalism Research, 2(2): 235-256.

Communication Commission of Kenya (2018). Telecommunications. Retrieved on August 2, 2009, from http://www.cck.go.ke/ telecommunications/.

Cray, G. (1998). Postmodern culture and youth discipleship. Cambridge, UK: Grove Books.

Damasio, A. R. (1995). Descartes' error: Emotion, reason, and the human brain. (1 $1^{\text {st }}$ ed.). New York: Harper Perennial.

Daniels, M. (2017). First-ever study on fake news in Kenya reveals scale of issue and impact on trust in media. July 19, Retrieved from 
www.kachwanya.com.

Dill, K. E. (2009). How fantasy becomes reality: Seeing through media influence. (1st ed.). New York: Oxford University Press.

Djafarova, E, and Rushworth, C. (2017). Exploring the credibility of online celebrities' Instagram profiles in influencing the purchase decisions of young female users. Computers in Human Behavior, 68: 1-7.

Gamson, J. (1994). Claims to Fame: Celebrity in Contemporary America. Berkeley: University of California Press.

Geneva (2003). World summit on information. WSIS/PCIP/DT/1(Rev.1)E. Retrieved September 23, 2009, from www.itu.int/.../S03WSISPCIP-030721-TD-GEN-0001!R1!MSW-E.doc.

Global Legal Monitor (2014). Kenya: Parliament passes comprehensive marriage bill, changes process for contracting customary marriages. Retrieved from www.loc.gov/law/foreignnews/article/kenya-parliament-passes-comprehensive-marriage-billchanges-process-for-contracting-customary-marriages/.

Grant, B. (N.D). The commodification of culture and its implications for the television industry: An examination of the culture industry thesis. Retrieved on October 22, 2009, from http://barneygrant.tripod.com/ cultureindustry.htm.

Grunlan, S. A., and Mayers, M. K. (1988). Cultural Anthropology: A Christian Perspective. 2nd Ed. Grand Rapids, MI: Zondervan.

Hearn, A. (2015). "Commodification." Keywords for media studies. Eds. Jonathan Gray and Laurie Ouellette. New York: New York University Press.

Hennessy, R. (2018). Profit and pleasure: Sexual identities in late capitalism. New York, NY: Routledge.

Honneth, A. (2008). Reification and recognition: A new look at the old idea. New York, NY: Oxford University Press.

Jethani, S. (2012). Media and the mind of Christ: How we see the world precedes what we do (Web blog post). Retrieved from http://www.qideas.org/blog/media-and-the-mind-of-christ.aspx.

Jhally, S. (2017). Advertising in the edge of the apocalypse. Retrieved from http://www.mediaed.org.

Kamary, B. (2013). New media as culture former in Kenya and Korea: A comparative study. (Unpublished doctoral dissertation). Kosin University, Busan, Korea.

Kasoma, F. P. (1995). The role of the independent media in Africa's change to democracy. Media, Culture and Society, 17(3): 537-555.

Kasoma, F. P. (1996). The foundations of African ethics (Afriethics) and the professional practice of journalism: The case for society-centered media morality. Africa Media Review, 10(3): 93-116.

Katz, E., Lazarsfeld, P. F., and Roper, E. (2017). Personal influence: The part played by people in the flow of mass communications. London, UK: Routledge

Kenya Film Commission (2017). Audience Consumer Trends Survey. Retrieved from http://www.kenyafilmcommission.com.

Khandizaji, A. (2017). Baudrillard and the culture industry: Returning to the first generation of the Frankfrurt School. Berlin, Germany: Springer.

Kracauer, S. (1995). The mass ornament: Weimar essays. Cambridge, MA: Harvard University Press.

Levy, D. A., and Nielsen, R. K. (2010). The changing business of journalism and its implications for democracy: Reuters Institute for the Study of Journalism. Retrieved from https://reutersinstitute. politics.ox.ac.uk.

Marx, K. (1867a) [1977]. Capital: A critique of political economy volume 1. London: Lawrence \& Wishart.

Marx, K. (1867b) [1977]. Preface to the first German edition of 'Capitalvolume 1. London: Lawrence \& Wishart.

Maweu, J. (2014). A clash between journalistic and capitalist values? How advertisers meddle in journalists' decisions at the Nation Media Group in Kenya. Journal of African Media Studies, 6(1): 27-42.

Mbenywe, M. (2018). KFCB bans 'Rafiki' film for depicting homosexual content. Retrieved from www.standardmedia.co.ke.

Mbiti, J. S. (1991). Introduction to African religion. 2nd Ed. Nairobi, Kenya: East African.

McCombs, M. (2014). Setting the agenda. Malden, MA: USA, Polity Press.
Musa, D. (1996). The sleeping dog cannot bark: Media and mass disempowerment of civil society in Africa. Africa Media Review, 10(3): 79-92.

Ndegwa, S. (2017). Kenya's current and future advertising fortunes. November 17. Retrieved from https://businesstoday.co.ke.

Ngetich, J. (2016). Survey: Media the most trusted institution. Retrieved from www.standardmedia.co.ke/.

Nuviadenu, K. (2017). Media globalization and localization: An analysis of the international flow of programs on Ghana Television (GTV). Global Media Journal, 4(7).

Ogbonnaya, O. A. (2001). African ways: A Christian education philosophy. Chicago, IL: Urban Ministries.

Opiyo, P. (2009, January 24). Media most trusted institution in Kenya. The East African Standard Newspaper.

Postman, N. (1985). Amusing ourselves to death: A public discourse in the age of show business. Middlesex, England: Penguin Books.

Rajula, T. (2018). Ezekiel Mutua bans Kenyan film about lesbians. Retrieved from https://www.nation.co.ke.

Rosenstiel, T., and Kovach, B. (2014). The elements of journalism: What newspeople should know and the public should expect. New York, NY: Three Rivers.

Santoro, L. (1998). Kenya brides that can't be bought: A few begin to tight a tradition. The Christian Science Monitor. Retrieved from https://www.csmonitor.com.

Schmidt, C. (Ed.) (2015). Kenya's media landscape: A success story with serious structural challenges. Leipzig, Germany: VISTAS Verlag.

Taylor, P. A., and Harris, J. L. (2008). Critical theories of mass media: Then and now. New York, NY: Open University Press.

Thornton, B. (2000). Greek ways: How the Greeks created Western civilization. California, CA: Encounter Books.

Tomsic, S. (2015). The capitalist unconscious. London, UK: CPI Mackays.

Ziegler, D., and Asante, M. K. (1992). Thunder and Silence. Trenton, NJ: Africa World.

Citation: Kamary, B. (2018). Commodification in mass media's educative function in Kenya: How now shall we think? African Educational Research Journal, 6(3): 137-147. 